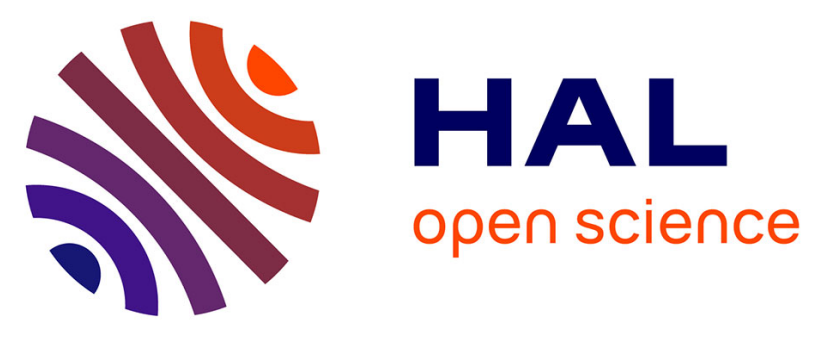

\title{
Solar Water Heating: Possibilities of Use in Industrial Processes in Brazil
}

Etevaldo Francisco Carreira Junior, Walter C. Satyro, Jose B. Sacomano, José Celso Contador

\section{- To cite this version:}

Etevaldo Francisco Carreira Junior, Walter C. Satyro, Jose B. Sacomano, José Celso Contador. Solar Water Heating: Possibilities of Use in Industrial Processes in Brazil. IFIP International Conference on Advances in Production Management Systems (APMS), Sep 2016, Iguassu Falls, Brazil. pp.852-859, 10.1007/978-3-319-51133-7_100 . hal-01615772

\section{HAL Id: hal-01615772 \\ https://hal.inria.fr/hal-01615772}

Submitted on 12 Oct 2017

HAL is a multi-disciplinary open access archive for the deposit and dissemination of scientific research documents, whether they are published or not. The documents may come from teaching and research institutions in France or abroad, or from public or private research centers.
L'archive ouverte pluridisciplinaire HAL, est destinée au dépôt et à la diffusion de documents scientifiques de niveau recherche, publiés ou non, émanant des établissements d'enseignement et de recherche français ou étrangers, des laboratoires publics ou privés.

\section{(c)(1)}

Distributed under a Creative Commons Attribution| 4.0 International License 


\title{
Solar Water Heating: Possibilities of Use in Industrial Processes in Brazil
}

\author{
Etevaldo Francisco Carreira Junior, Walter C. Satyro, José B. Sacomano, and \\ José Celso Contador \\ Paulista University, São Paulo, Brazil \\ fit.representacoes@uol.com.br
}

\begin{abstract}
The increase of the global energy consumption generated the search for alternative sources of energy, including solar. This study aims to identify the current stage and the possibilities of the application of solar water heating for industrial processes and to characterize the current state of the solar sector in Brazil. This study is based on bibliographic review and secondary data. The findings indicate that the use of solar water heating is a viable alternative for industrial processes in Brazil, mainly in the sectors of food, beverages, textiles and chemicals. The industrial sector is big and one of the the largest final consumer of electricity; although, the Brazilian development programs for the use of solar energy stimulate residential applications, a contradiction. The research also indicates that there is a lack of professionals specialized in renewable energies to work with solar heating systems in Brazil.
\end{abstract}

Keywords: Water Heating · Solar Heating · Alternative Energy · Renewable Energy · Industrial Processes.

\section{Introduction}

The technological advances and the economic and social development have demanded an increase of energy consumption; although, the alternative energy sources have a low share in the total volume of energy production around the world. The energy consumption for industrial purposes represents $29 \%$ of the total world consumption, and the use of alternative energy sources, including geothermal, solar, wind, heat etc. has a share of $1.2 \%$ [1].

The world industrial consumption of renewable energy accounts for $9 \%$, and $8 \%$ from this comes from biomass with low participation of other alternative sources, including solar energy [2].

In 2014 the Brazilian industry consumed $32.9 \%$ of the total energy generated, but only $4.1 \%$ of this came from alternative renewable energy. The industries in Brazil are the largest consumer of electricity, followed by the sectors of transport, public use, residential, agricultural and commerce [3].

Almost all industrial processes require heat; $15 \%$ of the total energy consumed by industry is for heating, $13 \%$ of the thermal industrial applications require temperatures up to $100^{\circ} \mathrm{C}$ and $27 \%$ up to $200^{\circ} \mathrm{C}$. [4]. 
Although in Brazil the industry is the largest consumer of electricity and the country is among the five with the largest area of solar collectors installed in the world, in 2014 water solar heating predominated in homes installations with $51 \%$, while in industries it represented $17 \%$ of the total [5].

The research question is: Why the Brazilian industries have not yet awakened to the use of solar energy for water heating supply for industrial processes? This study aims to identify the current stage and the possibilities of the application of solar water heating for industrial processes, potential barriers, more favorable industrial sectors and characterize the current state of the solar sector in Brazil.

\section{Methodology}

As a strategy of search to collect data we used bibliographic research $[6,7]$, in international and national articles of relevant scientific publications to build the theoretical framework, in a qualitative approach [6].

The exploratory research guided the collection of secondary data from the Brazilian market of solar water heating. For this, we tried to get the most up-todate information available in the Brazilian Government websites and at FIESP - Federation of the Industries of the State of Sao Paulo, which comprises 131 associated unions, divided into 23 productive sectors that represent 150,000 companies of various sizes of the production chain in the state of Sao Paulo, Brazil $[8]$.

\section{Literature Review}

\subsection{The Solar Water Heating in Industrial Processes}

Not all temperature levels required for industrial processes can be supplied by renewable energy sources, but the solar energy is adequate for low temperature applications (up to $100^{\circ} \mathrm{C}$ ) [2]. The industries search for efficient and costeffective methods to capture, store and convert solar energy into useful energy to obtain hot water and steam.

The industrial applications more compatible with the integration of solar energy systems are pre-heating, pasteurization, sterilization, washing, cleaning, chemical reactions, food preparation and textile processes. Due to the fact that solar energy is intermittent, the heated water should be accumulated to controlled consumption, and when necessary, receive additional heat from another source [9].

The main component of a solar power system is the collector. Solar thermal collectors can be: (1) stationary (without mechanisms to track the sun, installed oriented to the north with a horizontal tilt angle approximately equal to the local latitude), (2) mobile (with tracking of a single axis to follow the sun or with two systems axes perpendicular to each other following the sun in the East-West and North-South directions), and (3) the most common, the flat plate collector, 
suitable for temperatures up to $80^{\circ} \mathrm{C}$, and evacuated tubes for temperatures up to $130^{\circ} \mathrm{C}[10]$.

The selection of the heating system depends on the temperature required for the process. The most efficient systems and better cost / benefit are those for pre-heating, with flat plate collectors [4]. The solar heating for industrial processes is still in its early stages of development, but there would be great possibilities for applications with plan collectors and with evacuated tubes for temperatures up to $250^{\circ} \mathrm{C}$, such as in the food industry, textiles and beverages [10].

The potential use of solar heat for industrial processes are the ones that require temperatures up to $100^{\circ} \mathrm{C}$, mainly in the sectors of food and beverages, textiles and chemicals [11]. In the European region it is possible to find solar water heaters used in industrial processes $[12,13,14]$.

\subsection{Overview of the Brazilian Industrial Sector}

We present some data of the Brazilian industry, represented by the manufacturing industry, the mining industry and the industrial services of public utility (composed by water, electricity etc.) in Table .

Table 1. Size of the Brazilian industrial sector (Source: Adapted [15])

\begin{tabular}{lccc}
\hline & GDP (\%) & $\begin{array}{c}\text { Formal } \\
\text { Employment (\%) }\end{array}$ & $\begin{array}{c}\text { Industrial } \\
\text { Plants (\%) }\end{array}$ \\
\hline Manufacturing Industry & 10.9 & 15.7 & 8.9 \\
Mining Industry & 4.0 & 0,5 & 0.2 \\
Industrial Services of & 2.0 & 1 & 0.3 \\
Public Utility & & 17.2 & 9.4 \\
Total (Brazilian Industry) & 16.9 & (8.5 million people) & $(376,035$ plants) \\
\hline
\end{tabular}

The industrial Brazilian sectors more relevant to the GDP were in this order: food products ( $15.2 \%$ of added value of the Manufacturing Industry), coke, oil products and biofuels (10.5\%) and motor vehicles, vehicle body and auto parts $(9.5 \%)[15]$.

The industrial sectors of: food, beverages, textiles (including clothing and leather) and chemicals (including pharmaceuticals), that possess the greater potential for application of solar water heating systems, have their important data in the Brazilian industry shown in Table 2, where the formal employment and industrial plants percentages are in relation to the total manufacturing industry.

\subsection{The Solar Water Heating Sector in Brazil}

In Brazil the solar heating sector is officially presented by DASOL - National Department of Solar Heating [5], founded in 1992, which had as members $14 \%$ 
Table 2. Potential industrial sectors for thermal solar energy in Brazil (Source: Adapted [15])

\begin{tabular}{c|c|c|c|c|c}
\hline Sectors & $\begin{array}{r}\text { GDP } \\
\mathbf{( \% )}\end{array}$ & $\begin{array}{c}\text { Formal } \\
\text { Employment (\%) }\end{array}$ & $\begin{array}{c}\text { Employment } \\
\text { (No. of people) }\end{array}$ & $\begin{array}{c}\text { Industrial } \\
\text { Plants (\%) }\end{array}$ & $\begin{array}{c}\text { Industrial } \\
\text { Plants (No.) }\end{array}$ \\
\hline \hline Food & 1.8 & 19.7 & $1,531,732$ & 12.9 & 45,393 \\
Beverage & 0.4 & 1.8 & 138,25 & 0.7 & 2,436 \\
Textiles & 0.2 & 3.8 & 296,028 & 3.2 & 11,307 \\
Chemicals & 0.9 & 3.6 & 282,389 & 2.6 & 9,196 \\
Total & $\mathbf{3 . 3}$ & $\mathbf{2 8 . 9}$ & $\mathbf{2 , 2 4 8 , 3 9 9}$ & $\mathbf{1 9 . 4}$ & $\mathbf{6 8 , 3 3 2}$ \\
\hline
\end{tabular}

of the 200 companies in the Brazilian industry that dealt with solar energy. The national producers associated to DASOL produced plain solar collectors, that warmed the water from $30^{\circ} \mathrm{C}$ up to $80^{\circ} \mathrm{C}$, and also solar collectors of vacuum tubes that had a market share of only $1.1 \%$.

Austria, Brazil, China, India and Germany represented together more than $82 \%$ of the installed capacity in operation, and China was the largest user of solar thermal collectors in operation [16].

Brazil was the fifth country of accumulated area of installed solar collectors around the world, behind China, USA, Germany and Turkey, and in front of Australia, India, Austria, Greece and Israel, that formed the top 10 countries [16].

In 2014 the Brazilian solar thermal park produced 7,354 GWh, enough to supply with energy a city of about 3.7 million houses for a year, a city slightly smaller than Sao Paulo city. In this year, the accumulated area of installed solar collectors in Brazil was of 11.24 million $\mathrm{m}^{2}$, when 1.44 million $\mathrm{m}^{2}$ of solar collectors were produced.

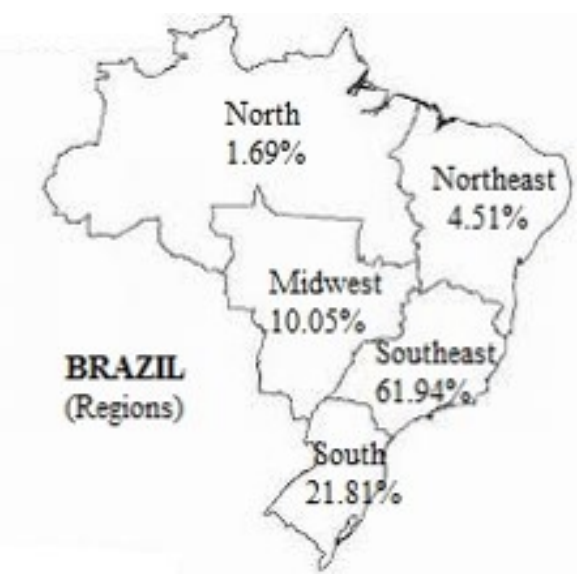

Fig. 1. Solar heaters purchases by regions of Brazil (Source: Adapted [5]) 
Among the Brazilian regions, the Southeast was the largest consumer of solar water heaters, representing $61.94 \%$ of the market, followed by the South $(21.81 \%)$ and by the Midwest region (10.05\%). The regions with smaller market shares in 2014 were the Northeast (4.51\%) and the North (1.69\%) [5], as shown in Figure 1.

DASOL also develops programs to increase the use of solar water heaters in towns, called "Solar Towns", but this initiative is based on the use of solar plain collectors for houses, not industrial processes [5].

\subsection{Aspects of the Viability of Solar Water Heating Systems}

The efficiency and viability of solar water heating systems depend first on the solar radiation intensity, so Brazil is a privileged territory, by abundant intensity of annual average insolation, and by the average number of daily hours of insolation. The Direct Normal Irradiation (DNI) in Brazil varied from 1200 to $2400 \mathrm{kWh} / \mathrm{m}^{2}$, as an average annual sum, in the period of $1999-2013$ [17].

Industrial applications of solar technology require higher temperatures and larger volumes than residential and commercial applications, and should consider: (1) where and when the high temperature is used, (2) the variable nature of the supply of solar energy as the process heat demand, and (3) the supply profile (including storage, cold water replacement and controls), investments and variables which make it problematic and difficult to integrate solar thermal processes and determine the savings generated by the solar system in relation to the consumption of conventional energy [18].

The viability of solar heating systems depends, beyond its initial cost, on the price of fuel and electricity used to produce heat that the solar system replaces, being more viable when the solar panels become cheaper and when the subsidy of fuel and electricity are removed [4,13].

The barriers to the use of solar thermal technology are: the simplistic financial view of return on investment, not considering conventional energy saving in the long run; ignorance of politicians, managers and decisions makers on solar energy uses; lack of documentation and specific technical literature, tools, training and professional qualification to design typical solar thermal systems for industries [10].

It is worth mention the lack of education on renewable energy and the reduced global efforts to introduce training in renewable energies in traditional training programs, as well as the need to include disciplines in this area in engineering courses, specific undergraduate courses and short courses to meet more immediately the industry demands, and the intensification of courses and workshops taught by industries of this sectors, as well as lectures, seminars, and the exchange of experiences between institutions etc. [10].

\section{Results and Discussion}

Solar is one of the most promising source of energy to supply the industry among the alternative renewable energies, although it still has a very low share in the 
energy matrix $[2,4,9,10,19]$. The most favorable applications are in the industrial sectors of food, beverages, textiles and chemicals, at low temperature process (up to $100^{\circ} \mathrm{C}$ ), for which the most suitable collectors are flat plate and evacuated tube $[10,13,14,20]$.

Brazilian industries have high potential for use of solar water heating systems, since the industrial park is large and diverse, having industries in all sectors considered as promising for the use of solar systems [8].

The Brazilian industry of food, beverage, textiles and chemicals represented together almost 30\% of the added value of the Manufacturing Industry, and $3.3 \%$ of the Brazilian GDP; and are responsible for 2,248,399 formal employments, having 68,332 industrial plants [8], as shown in Table 2.

If we considered that only $10 \%$ of all plants of these four industrial sectors could invest in solar water systems, we could have a potential area of 683,320 $\mathrm{m}^{2}$ of installed solar collectors (considering systems of $100 \mathrm{~m}^{2}$ ) to use in their processes. In addition, if $20 \%$ of the employees of the $2,248,399$ total people could take hot shower before going home, an additional potential area of $224,838 \mathrm{~m}^{2}$ would be required (considering $1 \mathrm{~m}^{2}$ collectors for every 100 liters of water and 50 liters of water per bath). So, adding those two areas, we could reach a potential area of almost 1 million $\mathrm{m}^{2}$ of solar water heaters, which would demand almost an additional 260 working days of the solar industry and would represent $8.9 \%$ of the already installed solar collectors in Brazil until 2014 [5].

Among the barriers identified to expand the use of solar thermal systems are: high costs considered of the systems, the low technological diffusion of solar heating to politicians, entrepreneurs, decision makers and potential users, the shortage of professionals with knowledge and experience in this area to design typical systems for industries, and even the lack of education and training in solar thermal engineering and in all professional levels: designers, installers, operators and maintainers, among others [21].

The use of electric shower for water heating is widespread in Brazil than nowhere else; as a result, electric showers are produced in large quantities at low price, representing an obstacle to the introduction of solar water heaters [21]. The use of solar water heaters could provide savings of up to $50 \%$ on electricity bill, with the return on investment varying from 1 to 24 months [5]. Due to the service life of 15 to 20 years on average, their use is advantageous [5].

On the other hand, the use of solar water heaters in industries had a growth from $3 \%$ in 2013 to $17 \%$ in 2014 , although its main use is to substitute the electric showers in the dressing rooms of the workers.

The National Energy Efficiency Plan [21] tries to provide efficient energy programs in solar water heaters, to stimulate and regulate the expansion of the use of these systems, that are: NORMASOL (to revise and elaborate standards), QUALISOL BRAZIL (to qualify suppliers), PROCEL - Brazilian Labeling Program (to establish comparison criteria of efficiency and quality of the models available in the market), SOLAR TOWNS (to promote primarily the use of solar water heaters) and LEGISLATION (federal, state and local laws, on obligation or incentive). 


\section{Conclusions}

The use of solar water heating systems in industrial processes, especially those using hot water at low temperature (up to approximately $100^{\circ} \mathrm{C}$ ) for direct use or for pre-heating processes of higher temperature, is an alternative viable for the Brazilian industry, especially in the food, beverage, textile and chemical sectors [9].

The use of solar water heaters could provide savings of up to $50 \%$ on electricity bill, with the return on investment varying from 1 to 24 months [5]. Due to the service life of 15 to 20 years on average, their use is advantageous [5].

The size of the Brazilian industrial market and the potential segments to the use of solar water heating systems makes it attractive from a marketing point of view, but only $17 \%$ of the industries use it, and in its majority, to substitute the electric showers in the dressing rooms of the workers, not for their processes [5].

Although Brazil is the fifth country of accumulated area of installed solar collectors around the world [16], there is much to do to increase the use of solar water heating systems in industrial processes, and the main difficulties are: the lack of culture and dissemination of knowledge and training to use these systems in the industrial environment, and the lack of incentives by the Brazilian development programs for the use of solar energy in industrial processes, stimulating the residential application, not the industrial application, which is one of the the largest final consumers of electricity, a contradiction.

This research hopes to contribute to industrial companies and educational institutions as an indicator of the opportunities for the use and for professional training in renewable energy applications, particularly solar, in Brazil.

\section{Acknowledgements}

The authors acknowledge CAPES - Coordenacao de Aperfeicoamento de Pessoal de Nivel Superior, Ministry of Education, Brazil, for the resources to make this research.

\section{References}

1. International Energy Agency: https://www.iea.org/publications/ freepublications/publication/key-world-energy-statistics-2015.html

2. Taibi, E., Gielen, D., Bazilian, M.: The Potential for Renewable Energy in Industrial Applications. Renewable and Sustainable Energy Reviews 16(1), 735-744 (2012)

3. Ministry of Mines and Energy: https://ben.epe.gov.br/downloads/Relatorio_ Final_BEN_2015.pdf

4. Kalogirou, S.: The Potential of Solar Industrial Process Heat Applications. Applied Energy 76(4), 337-361 (2003)

5. Nacional Department of Thermal Solar Energy: http://www.dasolabrava.org. br/informacoes/dados-de-mercado/ 
6. Martins, G. A., T.C.R.: Metodologia da Investigação Cientifica para Ciências Sociais Aplicadas. Atlas, São Paulo (2009)

7. Creswell, J.W.: Projeto de Pesquisa: Metodos Qualitativo, Quantitativo e Misto. Artmed, Porto Alegre (2010)

8. Federation of the Industries of the State of Sao Paulo: http://www.fiesp.com. br/sindicatos/

9. Mekhilef, S., Saidur, R., Safari, A.: A Review on Solar Energy Use in Industries. Renewable and Sustainable Energy Reviews 15(4), 1777-1790 (2011)

10. Cottret, N.; Menichetti, E.: http://www.solarthermalworld.org/sites/gstec/ files/story/2015-10-14/solar_heat_for_industrital_process_technical_ report._state_of_the_art_in_the_mediterranean_region.pdf

11. Vannoni, C., B.R.D.S.: http://www .aee-intec.at/Ouploads/dateien561.pdf

12. Quijera, J.A., Alriols, M.G., Labidi, J.: Integration of a Solar Thermal System in a Dairy Process. Renewable Energy 36(6), 1843-1853 (2011)

13. Calderoni, M., Aprile, M., Moretta, S., Aidonis, A., Motta, M.: Solar Thermal Plants for Industrial Process Heat in Tunisia: Economic Feasibility Analysis and Ideas for a New Policy. Energy Procedia 30, 1390-1400 (2012)

14. Karagiorgas, M., Botzios, A., Tsoutsos, T.: Industrial Solar Thermal Applications in Greece: Economic Evaluation, Quality Requirements and Case Studies. Renewable and Sustainable Energy Reviews 5(2), 157-173 (2001)

15. DEPECON: http://www.fiesp.com.br/

16. Mauthner, F., W.W.S.D.M.: https://www.iea-shc.org/data/sites/1/ publications/Solar-Heat-Worldwide-2015.pdf

17. SOLARGIS: http://solargis.info/doc/_pics/freemaps/1000px/dni/ SolarGIS-Solar-map-DNI-Brazil-en.png

18. Atkins, M.J., Walmsley, M.R., Morrison, A.S.: Integration of Solar Thermal for Improved Energy Efficiency in Low-temperature-pinch Industrial Processes. Energy 35(5), 1867-1873 (2010)

19. Lauterbach, C., Schmitt, B., Jordan, U., Vajen, K.: The Potential of Solar Heat for Industrial Processes in Germany. Renewable and Sustainable Energy Reviews 16(7), 5121-5130 (2012)

20. Beath, A.C.: Industrial Energy Usage in Australia and the Potential for Implementation of Solar Thermal Heat and Power. Energy 43(1), 261-272 (2012)

21. Ministry of Mines and Energy: http://www.mme.gov.br/mme/galerias/arquivos/ noticias/2010/PNEf_-_Premissas_e_Dir._Basicas.pdf 